\title{
IMPLEMENTASI KEBIJAKAN KERJASAMA LUAR NEGERI SISTER PROVINCE DI PROVINSI JAWA TENGAH
}

\author{
Masrohatun \\ Fakultas Ilmu Sosial dan Ilmu Politik Universitas Islam Negeri Walisongo Semarang \\ E-mail: Masrohatun@gmail.com
}

\begin{abstract}
Abstrak
Penelitian ini bertujuan untuk mengetahui bagaimana implementasi kebijakan kerjasama luar negeri dan faktor-faktor yang menjadi pendukung serta penghambat dari implementasi kebijakan kerjasama luar negeri sister province di Provinsi Jawa Tengah. Penelitian ini menggunakan metode penelitian kualitatif dengan pendekatan deskriptif analitis, menunjukkan hasil yang disebabkan (1).Tidak adanya klausal kerjasama provinsi pada pasal 3 di dalam Pergub Provinsi Jawa Tengah No. 4 Tahun 2010, (2).Lemahnya komitmen dari sister province untuk mentaati perjanjian, (3).Komite bersama yang diagendakan bertemu tiap setahun sekali sebagai forum evaluasi, belum bisa berjalan (4).Peran dari masing-masing dinas, belum dilaksanakan dengan maksimal (5).Minimnya program-program kerjasama yang terealisir, (6).Data hasil investasi dan perdagangan ekspor maupun impor kurang terinci. Faktor-faktor pendukung antara lain; (1).Adanya transmisi kebijakan yang jelas dan konsisten dari Biro Otda dan Kerjasama ke dinasdinas terkait kerjasama luar negeri sister province, (2).Jumlah pegawai, sumber wewenang dan sumber anggaran yang cukup (3).Adanya action plan (seperti SOP). Faktor-faktor penghambat, antara lain: (1).Kemauan dan keinginan implementor dalam menindaklanjuti MoU kerjasama dalam bentuk kerjasama yang lebih teknis masih lemah (2).Kemampuan berbahasa asing yang masih lemah pelaksana menjadikan komunikasi dalam berkoordinasi antara Jawa Tengah dengan masingmasing sister province menjadi kurang komunikatif dan maksimal, (3).Jumlah dinas yang cukup banyak dan tersebar mempengaruhi penyebaran tanggungjawab kepada dinas-dinas yang berbeda sehingga menyulitkan koordinasi maupun komunikasi antar dinas yang terlibat kerjasama.

Kata Kunci: Sister Province, Implementasi Kebijakan, Faktor-Faktor Pendukung dan Penghambat Implementasi
\end{abstract}

Abstract

This study aims to determine how the implementation of foreign cooperation policy and the factors that support and inhibit the implementation of sister province's foreign cooperation policy in Central Java Province. This research uses qualitative research method with analytical descriptive approach, showing result caused (1).There is no clause of provincial cooperation in article 3 in Pergub Provinsi Jawa Tengah No. (3). The joint committee, which is scheduled to meet annually as an evaluation forum, has not been able to work (4). The role of each agency has not yet been implemented with maximum (5). The number of realized cooperation programs, (6).The data of investment and export and import are not detailed. Supporting factors include; (1).There is a clear and consistent policy transmission from Bureau of Autonomy and Cooperation to offices related to overseas sister province cooperation, (2).Number of employees, source of authority and sufficient budgetary resources (3). SOUP). Inhibiting factors include: (1). The willingness and willingness of the implementor in following up the MoU of cooperation in the form of more technical cooperation is still weak (2).The ability of foreign languages are still weak implementers make communication in coordination between Central Java with each sister province becomes less communicative and maximal, (3). The number of duties that are quite large and spread affects the dissemination of responsibilities to different departments making it difficult to coordinate and communicate between the agencies involved in cooperation.

Keywords: Sister Province, Policy Implementation, Supporting Factors and Implementation Inhibitors 


\section{A. PENDAHULUAN}

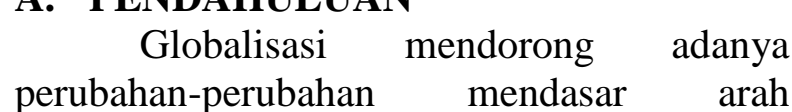
kebijakan nasional. Disadari atau tidak, globalisasi telah mendorong ketergantungan antar negara, salah satunya yakni kemajuan informasi dan kecanggihan teknologi. Dengan adanya kecanggihan teknologi, batas-batas wilayah negara satu dengan yang lainnya seakan tidak ada (borderless world) sehingga memudahkan untuk berinteraksi. Pemerintah daerah memiliki wewenang sejalan dengan adanya Undang-Undang No. 32 Tahun 2004 tentang Pemerintah Daerah, yang memberikan keleluasaan kepada Pemerintah Daerah untuk mengelola, meningkatkan daya saing, sehingga bisa mempromosikan hasil dan potensi daerahnya kepada negara luar guna meningkatkan kesejahteraan masyarakatnya. Ini sesuai dengan Undang-Undang No 32 Tahun 2004 tentang Pemerintahan Daerah, Pasal 195 yakni "Dalam rangka meningkatkan kesejahteraan rakyat, daerah dapat mengadakan kerjasama dengan daerah lain yang didasarkan pada pertimbangan efisiensi dan efektivitas pelayanan publik, sinergi dan saling menguntungkan.”

Bentuk kerjasama di era otonomi daerah cenderung lebih beragam jika dibandingkan dengan era sentralistik. Pemerintah daerah tidak hanya bisa melakukan kerjasama antar pemerintah daerah di dalam negeri melainkan dengan pemerintah daerah di luar negeri. Kerjasama tersebut antara lain kerjasama luar negeri sister province atau sister city. Dasar hukum pelaksanaan kerjasama luar negeri di Indonesia antara lain Peraturan Menteri Luar Negeri (Permenlu) No. 9 Tahun 2006 tentang Panduan Umum Tata Cara Hubungan dan Kerjasama Luar Negeri oleh Pemerintah Daerah dan Peraturan Menteri Dalam Negeri (Permendagri) No. 3 Tahun 2008 tentang Pedoman Pelaksanaan Kerjasama Pemerintah Daerah dengan Pihak Luar Negeri. Trend kerjasama luar negeri oleh Indonesia jumlahnya sudah cukup banyak, hingga mencapai lebih dari 200 bentuk kerjasama, baik dalam bentuk kerjasama sister province maupun sister city. Ketertarikan untuk menjalin kerjasama luar negeri juga dialami oleh Pemerintah Provinsi Jawa Tengah. Provinsi ini sudah menjalin 4 kerjasama luar negeri sister province. Sister province pertamanya adalah dengan negara bagian Queensland (Australia) tahun 1992. Sepuluh tahun berikutnya disusul kerjasama dengan Fujian (China) dan Chungcheongbuk-Do (Korea Selatan) di tahun 2003 kemudian dengan Siem Reap tahun 2007. Sebagai bentuk keseriusan Provinsi Jawa Tengah untuk merintis kerjasama sister province, Provinsi Jawa Tengah mengeluarkan Peraturan Gubernur (Pergub) Jawa Tengah No.4 Tahun 2010 tentang Pedoman Pelaksanaan Kerjasama Pemerintah Provinsi Jawa Tengah dengan pihak luar negeri.

Pelaksanaan kerjasama sister province yang sudah lama dijalani Provinsi Jawa Tengah setelah 20 tahun masih mengalami beberapa masalah maupun kendala. Kendala tersebut diantaranya Pergub Jateng No. 4 Tahun 2010 tentang Pedoman Pelaksanaan Kerjasama Pemerintah Provinsi Jawa Tengah dengan Pihak Luar Negeri sebagai peraturan resmi dan pedoman dari pelaksanaan kerjasama luar negeri di Provinsi Jawa Tengah tidak mencantumkan klausal kerjasama provinsi di dalam bentuk kerjasama antar pemerintah daerah. Padahal selama Pergub tersebut mulai diberlakukan, peraturan ini sudah meresmikan dua perpanjangan kerjasama sister yaitu dengan Queensland (Australia) di tahun 2012 dan dengan Fujian (China) di tahun 2014. Selain itu secara prosedur atau peraturan yang berlaku, yaitu MoU, 3 sister dari 4 sister province belum bisa mentaati aturan yang dibuat bersama seperti mundurnya masa berlakunya kerjasama yang seharusnya 5 tahun seperti yang sudah disepakati bersama di dalam MoU. Seperti sister province dengan Fujian, 
kerjasama ini seharusnya memasuki periode ketiga MoU kerjasama namun di tahun 2014 baru ditandatangai MoU yang ke-2. Dengan Chungcheongbuk-do, kerjasama ini seharusnya sudah memasuki MoU ke-3 namun sampai sekarang juga belum diperbaharui. Begitu pula dengan Siem Reap, kerjasama yang semestinya sudah memasuki MoU tahap ke-2, namun sampai sekarang belum menunjukkan adanya tanda-tanda perpanjangan MoU. Selain masalah kedisiplinan, realisasi bentuk bidang yang dikerjasamakan juga menunjukkan hasil yang kurang maksimal. Kurang maksimalnya realisasi salah satunya bisa dari pelaksanaan kerjasama dengan Siem Reap, di mana dari 6 agenda yang dikerjasamakan baru dua yang terlaksana.

Berlandaskan dari beberapa fenomena yang terjadi, penelitian ini bertujuan untuk mengetahui bagaimana implementasi kebijakan kerjasama luar negeri dan faktorfaktor yang menjadi pendukung serta penghambat dari implementasi kebijakan kerjasama luar negeri sister province di Provinsi Jawa Tengah.

\section{B. METODE PENELITIAN}

Metode yang digunakan adalah pendekatan kualitatif, sedangkan teknik pengumpulan data melalui wawancara dan observasi serta penelusuran berbagai sumber dan literatur baik dari dokumen pemerintah maupun pemberitaan media massa cetak dan elektronik, jurnal dan buku-buku yang terkait dengan kerja sama sister province. Data primer dan sekunder tersebut diolah dan dideskripsikan dalam bentuk narasi sesuai dengan kebutuhan data dan pembahasan. Selanjutnya dilakukan proses analisis data berdasarkan temuan penelitian, teori dan konsep untuk kemudian dilakukan proses intrepretasi data.

\section{PEMBAHASAN}

1. Kerjasama Luar Negeri Sister Province di Provinsi Jawa Tengah

Fenomena kerjasama luar negeri sister province oleh Indonesia memang sudah cukup banyak dilakukan oleh beberapa provinsi setelah adanya Peraturan Menteri Dalam Negeri (Permendagri) No. 1 Tahun 1992 tentang Penyelenggaraan Hubungan dan Kerjasama Luar Negeri. Kebijakan lain yang turut menguatkan kebijakan tersebut adalah UU No. 32 tahun 2004 tentang Pemerintah Daerah yang di dalamnya mengamanatkan pemerintah daerah untuk menyelenggarakan urusan pemerintahan yang menjadi wewenangnya, kecuali urusan pemerintahan yang oleh undang-undang ditentukan menjadi urusan pemerintah.

Dengan berjalannya waktu, Permendagri No. 1 Tahun 1992 digantikan oleh Permendagri No.3 tahun 2008 tentang Pedoman Pelaksanaan Kerjasama Pemerintah Daerah dengan Pihak Luar Negeri. Sejak dikeluarkannya Permendagri No.1 tahun 1992 sampai dengan digantikannya Permendagri No.3 tahun 2008, Jawa Tengah sudah menjalin 4 kerjasama sister province, yaitu: negara Bagian Queensland (Australia) dimulai tahun 1992, Fujian (China) dan Chungcheongbuk-do (Korea Selatan) di tahun 2003 dan dengan Siem Reap (Kamboja) di tahun 2007.

Kerjasama luar negeri Sister province di Jawa Tengah mulai dirintis pada Tahun 1991 oleh bapak Susmono yang pada saat itu merupakan kepala BKPMD (Badan Kordinasi Penanaman Modal Daerah) Jawa Tengah yang sekarang berganti nama menjadi BPMD atau Badan Penanaman Modal Daerah (Ahmad Sururi, 2008:19). Pada tahun 1992, dengan mendapatkan persetujuan dari Dewan Perwakilan Rakyat Daerah (DPRD) Provinsi Jateng, Jawa Tengah melakukan penandatanganan Memorandum of Understanding (MoU) oleh H. M Ismail selaku Gubernur Jawa Tengah dan Wayne Goss selaku Premier Negara Bagian Queensland Australia. Kerjasama sister 
province Queensland merupakan kerjasama pertama yang dijalin oleh Provinsi Jawa Tengah (Jateng) dengan pihak luar negeri.

Untuk melaksanakan kerjasama sister province maka dibutuhkan aktor pelaksana sebagai implementor dari sebuah kebijakan. Seperti yang diklasifikasikan oleh Anderson dalam Kusumanegara (2010: 100) bahwa aktor-aktor implementasi antara lain adalah birokrat, legislatif dan kelompok kepentingan. Birokrasi dalam hal ini diartikan sebagai administrasi yang paling bertanggungjawab dalam implementasi kebijakan. Selain itu, menurut Anderson, peran birokrasi yang dominan dalam implementasi cukup menjadikannaya sebagai aktor yang powerful, karena diskresi kebijakan tidak disertai kontrol eksternal yang cukup sehingga secara politik birokrat kuat pula secara politik. Jika disesuai dengan kenyataan, aktor-aktor kerjasama luar negeri sister province di Jateng memiliki peran sebagai birokrat yang memiliki full power terhadap tugas dan fungsinya masing-masing.

Adapun peran dari masing-masing aktor pelaksama kerjasama sister province di Jateng adalah sebagai berikut:

1. Gubernur, berperan sebagai penyelenggara sekaligus pemegang fungsi engawasan dan pembinaan sesuai dengan Pergub Provinsi Jawa Tengah No.4 tahun 2010 tentang Pedoman Pelaksanaan Kerjasama Provinsi Jawa Tengah dengan Pihak Luar Negeri.

2. DPRD, memberikan ijin melakukan kerjasama sister province.

3. Biro Otonomi daerah dan Kerjasama, Bagian Kerjasama Luar Negeri, membantu tugas Gubernur

4. BPMD, mendatangkan investor dengan mempromosikan potensi yang ada dan dimiliki Jawa Tengah

5. Dinas Kesehatan enjadi fasilitator sekolah-sekolah di Jawa Tengah yang ingin menjalin kerjasama sister school dengan sekolah-sekolah di provinsi sister province
6. Dinas Kesehatan, melanjutkan kerjasama yang sudah dijalin oleh Dinas Kesehatan dengan University of Techology, Queensland

7. Dinas Kebudayaan dan Pariwisata, mempromosikan budaya dan tempattempat wisata di Jawa Tengah

8. Dinas Perindustrian dan Perdagangan, setiap ada event menginformasikan kepada pengusaha Jateng supaya mereka bisa berpartisipasi untuk mempromosikan produk-produk yang dimiliki kepada pengusaha yang ada di provinsi sister Jawa Tengah agar tertarik untuk membeli.

Sebelum program kerjasama sister province bisa diimplementasikan Provinsi Jawa Tengah harus mentaati prosedur penyelenggaraan kerjasama pemerintah Jawa Tengah dengan pihak Luar Negeri, sesuai dengan Pergub Jateng No.4 tahun 2010 sebagai berikut:

1. Pihak luar negeri menyampaikan rencana prakarsa kerjasama ke pemerintah daerah (Pemda) Jateng

2. Pemda menyampaikan prakarsa kerjasama dengan Mendagri

3. Kementerian Dalam Negeri (Kemendagri) menyampaikan pertimbangan atas prakarsa kerjasama dengan Pemda Jateng

4. Dasar pertimbangan dari Kemendagri, Pemda Jateng menyusun rencana kerjasama (RK). Kemudian RK tersebut disampaikan kepada DPRD untuk mendapatkan persetujuan.

5. Berdasarkan persetujuan DPRD, Pemda atau Gubernur Jateng menyusun rancangan MoU yang disampaikan ke DPRD lagi

6. DPRD menyampaikan rancangan $\mathrm{MoU}$ kepada Kemendagri untuk dibahas

7. Kemendagri menyampaikan rancangan MoU pada Menteri Sekretaris Negara (Mensegneg)

8. Mensegneg mengeluarkan surat persetujuan pemerintah

9. Berdasar persetujuan Mensegneg, Kemendagri mengirimkan rekomendasi 
kepada Menteri Luar Negeri (Menlu) untuk penerbitan full power .

10. Menlu menerbitkan surat kuasa atau MoU untuk ditandatangani.

\section{a. Sister Province dengan Queensland (Australia)}

Queensland merupakan sister tertua dibanding dengan sister lainnya dalam bingkai kerjasama luar negeri siter province di Provinsi Jawa Tengah. Usianya kurang lebih 22 tahun terhitung dari tahun 1992. Dalam pelaksanaannya, kerjasama ini terbilang paling efektif jika dibandingkan dengan kerjsama lainnya. Sejak mulai didirikan 1992 sampai sekarang, sudah ada 5 kali perpanjangan MoU, yang terakhir di tahun 2012 lalu. Kerjasama ini diresmikan pada 18 Maret 2012 sampai 2017 oleh Bibit Waluyo, sebagai Gubernur Provinsi Jawa Tengah dan Campbell Newman MP, Premier negara bagian Queensland Australia. Action plan yang dibuat didiskusikan bersama, jika tidak bisa bertemu biasanya dilakukan via email atau telpon. Selain itu, bidang-bidang yang dikerjasamakan sudah banyak yang berjalan terutama di bidang pendidikan dan kesehatan.

\section{b. Sister Province dengan Fujian (China)}

Kerjasama ini diresmikan dengan penandatanganan MoU oleh Gubernur Mardiyanto dan Wakil Gubernur Fujian Wang Meixiang tahun 2003. MoU yang sudah disahkan tahun 2003, baru diimplementasikan pada tahun 2012-2013 yaitu dengan dibentuknya komite bersama kedua provinsi. Memorandum of Understanding ke-2 kerjasama sister province Jateng-Fujian, ditandatangani oleh Gubernur Provinsi Jawa Tengah Ganjar Pranowo dan Gubernur Fujian Su Shulin melalui desk to desk di Fujian pada 11 Januari dan 18 Februari tahun 2014 di Semarang.

Kerjasama ini satu dari beberapa kerjasama sister province yang kurang efektif. Ini bisa dilihat dari keterlambatan dalam implementasi program kerjasama yang diagendakan, yang mana program tersebut baru terlaksana di tahun 2012, padahal MoU sudah dimulai sejak 2003. Selama masa 9 tahun seharusnya bisa digunakan untuk mengimplementasikan kerjasama dengan maksimal. Akan tetapi malah terbuang sia-sia tanpa ada yang dihasilkan. Dilihat dari sudut lainnya, kerjasama ini juga bisa dibilang kurang disiplin dalam mentaati MoU yang telah disepakati. Kerjasama yang seharusnya diperbaharui setiap 5 tahun sekali tidak diindahkan, bahkan telat untuk diperbaharui. Semestinya kerjasama ini sudah memasuki periode ke-3 MoU namun baru $2 \mathrm{MoU}$ yang ditandatangani.

\section{c. Sister Province dengan Chungcheongbuk-do (Korea Selatan) \\ Jalinan kerjasama Provinsi Jawa} Tengah dengan salah satu provinsi di negara ginseng ini sudah dimulai pada tanggal 8 Oktober 2003 dengan penandatanganan letter of intens (LoI) di Chengju, Korea Selatan. Kemudian ditindaklanjuti penandatanganan MoU kerjasama pada tanggal 28 Nopember 2004, oleh Murdiyanto, Gubernur Jawa Tengah dan dari Chungcheongbuk-Do oleh Lee Wong Jong di Semarang. Kerjasama ini termasuk dalam golongan kerjasama sister province yang kurang efektif juga. Seperti kasus Fujian yang tidak disiplin dalam mematuhi aturan yang sudah dituangkan di dalam MoU, kerjasama dengan Chungcheongbuk-do pun mengalami nasib yang hampir serupa. Kerjasama ini baru menandatangani 1 MoU padahal, secara perhitungan tahun mulai perjanjian Cungcheongbuk-do sudah memasuki periode ke-3 MoU.

\section{d. Sister Province dengan Siem Reap (Kamboja)}

Sister keempat dari provinsi Jawa Tengah yakni Siem Reap, Kamboja. Kerjasama ini dinamakan sister temple province. Cikal bakal kerjasama ini bermula dari adanya kerjasama candi kembar antara Borobudur, Jawa Tengah dengan Candi 
Angkor Wat, Kamboja. Kemudian, kerjasama ini berkembang menjadi beberapa fokus bidang yang dikerjasamakan. Jika dibanding dengan tiga sister Jateng yang lain, kerjasama dengan Siem Reap adalah kerjasama yang memperlihatkan bahwa Jawa Tengah lebih aktif dalam menggerakkan kerjasama. MoU kerjasama ini ditandatangani di Borobudur, Magelang pada tahun 2007 oleh perwakilan dari masing-masing provinsi. Provinsi Jawa Tengah diwakili oleh Asisten Tata Praja, Pudjo Kiswantoro dan Siem Reap diwakili Wagub Siem Reap HE Nou Phalla. Dalam pelaksanaannya, kerjasama sister province, Siem Reap mengalami permasalahan yang sama dengan Fujian dan Chungcheongbuk-do, yaitu kerjasamanya yang berjalan kurang efektif. Kekurangefektifan ini salah satunya ditandai oleh stagnasi kerjasama dari pihak Siem Riep yang tidak segera memperpanjang MoU kerjasama, yang seharusnya sudah memasuki MoU ke-3. Akan tetapi sampai sekarang, belum ada tanda-tanda kerjasama MoU tersebut akan diperpanjang. Bahkan contact person mereka tidak bisa dihubungi.

\section{Implementasi Kerjasama Luar Negeri Sister Province di Provinsi Jawa Tengah}

Pelaksanaan kerjasama sister province di Provinsi Jawa Tengah sesuai dengan Pergub Provinsi Jawa Tengah No.4 Tahun 2010 tentang Pedoman Pelaksanaan Kerjasama Pemerintah Provinsi Jawa Tengah Dengan Pihak Luar Negeri masih kurang legitimate untuk keberadaan sebuab landasan legal formal, antara lain karena Pergub yang digunakan sebagai pedoman pelaksanaan kerjasama luar negeri ini di dalamnya ada keteledoran penulisan, karena tidak mencantumkan klausal kerjasama provinsi (pasal 3a) di dalam Pergub tersebut padahal pada pasal berikutnya ada. Terlepas dari kesalahan redaksi atau yang lain, jika kesalahan ini dibiarkan maka kerjasama ini menjadi tidak sah. Padahal selama Pergub Jateng No. 4 diberlakukan, sudah dua kerjasama sister province yang diperpanjang yaitu dengan Queensland di tahun 2012 (MoU ke-5) dan dengan Fujian, China (MoU ke-2) di tahun 2014.

Beberapa sister province masih lemah dalam mentaati MoU. Ini seperti yang dikemukakan oleh beberapa informan dari hasil penelitian yaitu dari 4 sister province di Prov. Jateng, hanya Queensland yang memiliki komitmen cukup kuat untuk mentaati MoU yang ditetapkan bersama. Sedangkan 3 sister province lainnya yaitu dengan Fujian, Chungchengbuk-do dan Siem Reap kurang begitu taat pada perjanjian atau MoU yang ada, semisal masalah jangka atau batas waktu kerjasama. Batas waktu kerjasama sesuai draf MoU dari masingmasing kerjasama dalam pasal 8 seharusnya 5 tahun. Akan tetapi 3 sister province tersebut kurang mengindahkannya, sehingga perpanjangan MoU seringkali telat dari batas waktu yang ditentukan. Jika hal ini dibiarkan maka program-program yang sudah diagendakan selama 5 tahun melalui action plan dari masing-masing kerjasama tidak bisa berjalan dan kerjasamanya seakan menggantung tanpa hasil karena tidak ada kejelasan. Jika permasalahan ini dihubungkan dengan pendapat James Anderson (Kusumanegara, 2010:97) bahwa implementasi kebijakan/ program merupakan bagian dari administrative process (proses adminitrasi). Proses administrasi sebagaimana diistilahkan oleh Anderson, digunakan untuk menunjukkan desain atau pelaksanaan sistem administrasi mempunyai konsekuensi terhadap pelakasanaan, isi dan dampak suatu kebijakan. Maka secara administrasi pelaksanaan kerjasama sister province masih terdapat banyak kekurangan karena adanya permasalahan yang disebutkan di atas.

Kemudian kelompok kerja atau komite bersama yang dibentuk dari masing-masing kerjasama sister province yang diagendakan bertemu setiap tahun sekali sebagai forum evaluasi belum bisa terlaksana sesuai yang disepakati di MoU. Hal ini bisa dilihat dari koordinasi antara Jawa Tengah dengan para sister province, jika komite tersebut berjalan dengan baik maka kerjasama sister province 
tidak perlu mengalami stagnasi atau penundaan perpanjangan $\mathrm{MoU}$ yang dialami oleh sister province dengan Fujian, Chungcheongbuk-do dan Siem Reap.

Komite bersama atau kelompok kerja di dalam kerjasama sister province dibentuk dari beberapa dinas-dinas yang terkait kerjasama baik dari Provinsi Jawa Tengah dan masing-masing sister province. Komite ini di bawah tanggung jawab Biro Otda dan Kerjasama, Bagian Kerjasama Luar Negeri Pemerintah Prov. Jateng dan Kantor Urusan Luar Negeri atau dari masing-masing sister province (Queensland, Fujian, Chungcheongbuk-do dan Siem Reap). Biro tersebut akan bertanggung jawab sebagai penghubung dalam koordinasi komite bersama. Komite ini memang memiliki keuntungan sebagai alat koordinasi dari masing-masing dinas masing-masing sister province dengan dinas-dinas di Prov. Jateng. Komite bersama merupakan sekumpulan dinas yang ditunjuk untuk melaksanakan tugas tertentu. Karena dinas-dinas yang terkait jumlahnya lebih dari satu dan memiliki tugas dan fungsinya masing-masing, hal ini menjadikan dinas-dinas tersebut sedikit dilema akan mendahulukan tugas mana yang harus dilaksanakan terlebih dahulu ketika dari dinas tersebut juga memiliki program lainnya. Ini yang menjadi salah satu indikasi bahwa beberapa dinas yang terkait kerjasama sister province belum bisa menindaklanjuti kerjasama teknik. Selain itu tidak adanya struktur organisasi yang jelas di dalam komite bersama, juga menjadikan koordinasi dan manajemen organisasi menjadi lemah. Ini dikarenakan tidak ada kejelasan tanggungjawab.
Selain itu sesuai dengan hasil penelitian bahwa fungsi atau peran aktoraktor pelaksana kerjasama sister province di Provinsi Jawa Tengah belum maksimal dalam melaksanakan perannya masing-masing. Ini bisa dilihat dari komitmen dinas tersebut dalam menindaklanjuti kerjasama dalam bentuk kerjasama yang lebih teknis. Lima dinas yang terkait kerjasama, baru dua dinas yang sudah menindaklanjuti kerjasama dengan kerjasama teknik yaitu Dinas Pendidikan dan Dinas Kesehatan. Padahal dinas-dinas tersebut merupakan birokrasi, yang menurut Anderson, birokrasi adalah agen administrasi yang paling bertanggungjawab dalam implementasi kebijakan, mempunyai wewenang yang besar untuk sepenuhnya menguasai implementasi kebijakan dalam wilayah operasinya, maka dari itu seharusnya semua dinas terkait kerjasama sudah mulai menindaklanjuti kerjasama dengan kerjasama teknis.

Sedangkan sesuai dengan tujuan dari masing-masing $\mathrm{MoU}$ kerjasama sister province baik dengan Queensland, Fujian, Chungcheongbuk-Do dan Siem Reap, kerjasama sister province ini terkesan memprioritaskan bidang perdagangan, bisnis, industri dan investasi. Hal ini diperkuat dari data hasil penelitian bahwa hampir semua output kerjasama memperlihatkan adanya hubungan kerjasama perdagangan dan investasi yang lebih intens. Ini sesuai dengan pendapat (Badjuri, 2002: 72) bahwa penentuan tujuan akan menentukan prioritas kebijakan dan tindakan yang dilakukan untuk mengatasi permasalahan dalam proses implementasi. Terkait investasi bisa dilihat dari tabel berikut ini: 
Tabel. 1

Proyek dan Investasi dari Australia, China dan Korea Selatan

\begin{tabular}{|c|c|c|c|c|c|c|}
\hline \multirow[t]{2}{*}{ No } & \multirow[t]{2}{*}{ Negara } & \multicolumn{2}{|c|}{ Investasi } & \multirow[t]{2}{*}{ Proyek } & \multicolumn{2}{|c|}{$\begin{array}{c}\text { Penyerapan Jumlah } \\
\text { Tenaga Kerja }\end{array}$} \\
\hline & & Rupiah & US\$ & & Domestik & Asing \\
\hline 1. & Australia & 0 & 31.278 .163 & 13 & 0 & 202 \\
\hline 2. & China & 249.300 .000 .000 & 68.899 .282 & 19 & 5.142 & 0 \\
\hline 3. & Korea Selatan & 37.325 .000 .000 & 45.853 .965 & 62 & 31.193 & 12 \\
\hline
\end{tabular}

Keterangan: * triwulan pertama (Januari-April)

Tabel 2

Ekspor dan Impor dari dan ke Australia, China,

Korea Selatan dan Kamboja

Tahun 2009-2014*

\begin{tabular}{|c|l|r|r|r|r|}
\hline \multirow{2}{*}{ No } & \multirow{2}{*}{ Negara } & \multicolumn{4}{|c|}{ Kegiatan } \\
\cline { 3 - 6 } & & \multicolumn{2}{|c|}{ Ekspor } & \multicolumn{2}{c|}{ Impor } \\
\cline { 3 - 6 } & & Migas & \multicolumn{1}{c|}{ Non Migas } & \multicolumn{1}{c|}{ Migas } & \multicolumn{1}{c|}{ Non Migas } \\
\hline 1 & Australia & 0 & $689,677,778$ & $245,158,933$ & $1,362,815,191$ \\
\hline 2 & China & $336.991,152$ & $1,741,110,270$ & $281,606,240$ & $8,438,271,907$ \\
\hline 3 & Korea & $198,535.164$ & $774,543,520$ & $923,438,476$ & $884,352,677$ \\
& Selatan & & & & 0 \\
\hline 4 & Kamboja & 0 & $802,420,123$ & 029,231 \\
\hline
\end{tabular}

Sumber: Dinas Perindustrian dan Perdagangan Provinsi Jawa Tengah (diolah) 2014

Keterangan: * triwulan pertama (Januari-April)

Selain itu Realisasi program kerjasama yang masih minim seperti yang terlihat dalam tabel berikut ini:

Tabel 3

Realisasi Kerjasama Sister Province

\begin{tabular}{|c|c|c|c|}
\hline No & $\begin{array}{c}\text { Kerjasama } \\
\text { Sister Province }\end{array}$ & $\begin{array}{c}\text { Bentuk } \\
\text { Kerjasama }\end{array}$ & Realisasi \\
\hline \multirow[t]{2}{*}{1.} & \multirow[t]{2}{*}{$\begin{array}{l}\text { Jateng- } \\
\text { Queensland }\end{array}$} & $\begin{array}{ll}\text { a. Perdagangan } \\
\text { dan Invetasi }\end{array}$ & $\begin{array}{l}\text { - Impor Jateng dari Australia lebih tinggi } \\
\text { (US\$ 1,362,851,191), jika dibandingkan } \\
\text { dengan ekspor Jateng ke Australia } \\
\text { (US\$689,677,778) } \\
\text { Ada } 13 \text { proyek investasi dari Australia } \\
\text { sebesar US\$ } 31,278,163 \text { dengan } \\
\text { penyerapan tenaga kerja sebanyak } 2.467 \\
\text { (domestik) dan 202 (TKA) }\end{array}$ \\
\hline & & b. Pendidikan & $\begin{array}{l}\text { - Ada } 14 \text { Sekolah SMA yang menjalin } \\
\text { kerjasama sister school dengan sekolah } \\
\text { setingkat SMA di Negara bagian } \\
\text { Queensland }\end{array}$ \\
\hline
\end{tabular}




\begin{tabular}{|c|c|c|c|}
\hline & & c. Kesehatan & $\begin{array}{l}\text { - Dinkes Prov. Jateng menjalin kerjasama } \\
\text { dengan University of Technology } \\
\text { Queensland, guna meningkatkan mutu } \\
\text { tenaga medis di Jateng supaya diakui di } \\
\text { internasional }\end{array}$ \\
\hline & & d. Pemerintahan & $\begin{array}{l}\text { - Pemerintah Kota } \\
\text { kerjasama semarang menjalin } \\
\text { Brisbane }\end{array}$ \\
\hline 2. & Jateng-Fujian & $\begin{array}{l}\text { a. Perdagangan, } \\
\text { industri, } \\
\text { investasi, } \\
\text { bisnis dan } \\
\text { Pariwisata }\end{array}$ & $\begin{array}{l}\text { - Impor Jateng dari Australia lebih tinggi } \\
\text { (US\$ 8,719, 878,147), jika dibanding } \\
\text { dengan ekspor Jateng ke Australia (US\$ } \\
2,078,100,922 \text { ) } \\
\text { - Ada 19 proyek investasi dari China } \\
\text { sebesar US } \$ 8,889,282 \text { dan Rp } \\
249.300 .000 .000 \text { dan menyerap tenaga } \\
\text { kerja sebanyak 5.142 (domestik) } \\
\text { - Pemberian patung Laksamana Cheng Ho, } \\
\text { oleh warga Fujian } \\
\text { Yang diletakkan di Klenteng Sam Poo } \\
\text { Kong }\end{array}$ \\
\hline & & $\begin{array}{l}\text { b. Pengembangan } \\
\text { ekonomi di } \\
\text { sektor swasta }\end{array}$ & \\
\hline & & $\begin{array}{l}\text { c. Pengembangan } \\
\text { SDM }\end{array}$ & $\begin{array}{l}2 \text { Delegasi Jateng mengikuti pelatihan di } \\
\text { Fujian }\end{array}$ \\
\hline & & $\begin{array}{l}\text { d. Pendidikan dan } \\
\text { Budaya }\end{array}$ & $\begin{array}{l}\text { - Dindik Prov. Jateng tahun } 2014 \\
\text { menandatangani MoU dengan Deputy } \\
\text { Director General of Fujian }\end{array}$ \\
\hline & & $\begin{array}{l}\text { e. Kesehatan dan } \\
\text { lingkungan }\end{array}$ & \\
\hline 3. & $\begin{array}{l}\text { Jateng- } \\
\text { Chungcheongb } \\
\text { uk-do }\end{array}$ & $\begin{array}{l}\text { a. Perdagangan, } \\
\text { industri, } \\
\text { investasi dan } \\
\text { pariwisata }\end{array}$ & $\begin{array}{l}\text { - Kegiatan impor Jateng dari Korea Selatan } \\
\text { lebih tinggi yaitu sebesar US\$ } \\
1,807,791,153 \text { jk dibanding dgn eks } \\
\text { Jateng ke Korsel yakni US\$ 973,078,684 } \\
\text { - Ada } 62 \text { proyek investasi dr Korsel ke } \\
\text { Jateng sebesar US } \$ 4,853,965 \text { dan Rp } \\
37.325 .000 .000 \text { dan tenaga krj yang } \\
\text { terserap sebanyak 33. } 193 \text { (domestik) dan } \\
12 \text { tenaga asing }\end{array}$ \\
\hline & & $\begin{array}{l}\text { b. Pengembangan } \\
\text { ekonomi pada } \\
\text { sektor swasta }\end{array}$ & \\
\hline & & $\begin{array}{l}\text { c. Pendidikan dan } \\
\text { kebudayaan }\end{array}$ & $\begin{array}{l}\text { - Atlet Jateng yang dikirim ke } \\
\text { Chungcheongbuk-do berhasil meraih } \\
\text { medali dalam ajang PON pada tahun } \\
2004,2005,2007,2008 \text { dan } 2012 \text {. }\end{array}$ \\
\hline
\end{tabular}




\begin{tabular}{|c|c|c|c|}
\hline & & $\begin{array}{ll}\text { d. } & \text { Kesehatan dan } \\
& \text { lingkungan } \\
\end{array}$ & \\
\hline \multirow[t]{6}{*}{4.} & \multirow{6}{*}{$\begin{array}{l}\text { Jateng-Siem } \\
\text { Reap }\end{array}$} & a. Pariwisata & \\
\hline & & b. Kebudayaan & \\
\hline & & c. Pendidikan & $\begin{array}{l}\text { - Ada } 2 \text { SMPN, } 1 \text { SMAN dan SMA Taruna } \\
\text { dari Jateng yg menjalin sister school } \\
\text { dengan sekolah setingkat SMP dan SMA } \\
\text { di Siem Reap. }\end{array}$ \\
\hline & & d. Investasi & \\
\hline & & e. Industri & \\
\hline & & f. Perdagangan & $\begin{array}{l}\text { - Ekspor Jateng ke Kamboja lebih tinggi } \\
\text { yakni US } \$ 802,420,123 \text { jika dibanding } \\
\text { dengan impor Jateng dari Kamboja yg } \\
\text { hanya } 1,029,231 \text {. } \\
\text { - Investasi Kamboja ke Jateng belum ada }\end{array}$ \\
\hline
\end{tabular}

Tabel di atas menunjukkan bahwa outcome dari kerjasama sister province antara lain yaitu adanya penyerapan tenaga kerja sebanyak 40.802 orang. Atlet tekwondo Jateng bisa meraih medali emas dalam PON di tahun 2004, 2005, 2007, 2008 dan 2012 setelah diberi pelatihan di Chungcheongbukdo. Akan tetapi tidak semua kerjasama yang di MoUkan berjalan semua. MoU yang berjalan hanya dengan Queensland karena hampir semua program kerjasama bisa berjalan. Sedangkan dengan sister yang lain baik Fujian, Chungcheongbuk-do dan Siem Reap, beberapa program kerjasama yang diagendakan belum terlaksana. Beberapa program kerjasama yang terealisasi secara jelas adalah program-program yang tergolong government to government sedangkan untuk yang lainnya belum terlihat.

Kurang maksimal atau minimnya realisasi program kerjasama sister province bisa jadi karena kerjasama luar negeri sister province bukan merupakan urusan wajib dari pemerintah daerah untuk menjalankannya (Pasal 13, UU No. 32 Tahun 2004). Tabel tersebut juga menunjukkan adanya ketergantungan Jawa Tengah atas bahan migas maupun non migas dari negara sister province Jawa Tengah. Ketidakefektifan dari kerjasama sister province juga dilihat dari data hasil investasi dan perdagangan ekspor atau impor yang kurang mendetail. Data dari BPMD dan Dinperindag tidak mencantumkan dari negara bagian atau provinsi mana investasi itu didapat, dan dari serta ke negara bagian atau provinsi mana Jawa Tengah melakukan impor atau ekspor terutama Queensland, Fujian, Chungcheongbuk-do dan Siem Reap, sehingga hasil investasi dan perdagangan terlihat jelas.

\section{Faktor-Faktor Pendukung dan Penghambat Implementasi Kebijakan Kerjasama Luar Negeri Sister Province di Provinsi Jawa Tengah}

Sesuai hasil penelitian yang menggunakan model implementasi kebijakan menurut Edwards III, dengan 4 variabel yaitu (1) Komunikasi (communication), (2) Sumberdaya (resource), (3) Disposisi (disposition), (4) Struktur birokrasi (bureaucratic structures). Berikut adalah analisis dari hasil penelitian.

\section{Faktor Pendukung}

\section{a. Komunikasi}

Komunikasi merupakan salah satu faktor yang berperan penting dalam mempengaruhi keberhasilan sebuah kebijakan. Keberhasilan implementasi kebijakan mensyaratkan agar implementor mengetahui apa yang harus dilakukan. Apa yang menjadi tujuan dan sasaran kebijakan 
harus ditransmisikan kepada kelompok sasaran (target group) sesuai dengan pendapat Edwards (Subarsono,2005:90). Melihat betapa pentingnya komunikasi sesuai pendapat Edwards dalam implementasi kebijakan, maka hasil wawancara dalam penelitian ini tentang komunikasi yang dilakukan Pemerintah Daerah Provinsi Jawa Tengah yang dalam hal ini Gubernur atau yang membantu tugas Gubernur (Biro Otda dan Kerjasama, Bagian Kerjasama Luar Negeri Jawa Tengah) menyalurkan informasi ke dinas-dinas (BPMD, Dindik, Dinperindag, Dinbudpar dan Dinkes) yang terlibat kerjasama sister province berbentuk sosialisasi dan pembentukan komite bersama. Komite bersama dibentuk setelah MoU ditandatangani untuk menerjemahkan program dari bidang-bidang yang dikerjasamakan dalam bentuk action plan.

Biro Otda dan Kerjasama, Bagian Kerjasama Luar Negeri Bagian Kerjasama mensosialisasikan program-program kerjasama sister province, setiap setahun sekali di awal tahun atau setiap ada event. Selain transmisi, menurut Edwards III dalam Widodo (2010 :97) kejelasan (clarity) dalam komunikasi juga diperlukan guna menghendaki kebijakan yang ditrasmisikan kepada pelaksana, target grup dan pihak lain yang berkepentingan secara jelas sehingga di antara mereka mengetahui apa yang menjadi maksud, tujuan, sasaran, serta substansi dari kebijakan publik tersebut sehingga masingmasing akan mengetahui apa yang harus dipersiapkan serta dilaksanakan untuk mensukseskan kebijakan tersebut secara efektif dan efisien.

Sesuai dengan hasil wawancara bahwa sebagian besar dinas memahami komunikasi yang dilakukan oleh Bagian Kerjasama Luar Negeri Jawa Tengah, karena isi kebijakan atau MoU kerjasama dipahami secara jelas sehingga mereka bisa membuat program-program sesuai dengan yang diinginkan dan tidak keluar dari tugas dan fungsinya. Jika disesuaikan dengan pendapat Edwards III (Widodo,2010 : 97) bahwa kejelasan kebijakan, konsistensi (consistency) diperlukan agar kebijakan yang diambil tidak simpang siur sehingga tidak membingungkan pelaksana kebijakan, target grup dan pihakpihak yang berkepentingan. Hal tersebut sesuai dengan kondisi yang ada dalam komunikasi antara biro Otda dengan dinas terkait sehingga komunikasi (transmisi, kejelasan dan konsistensi) sudah berjalan dengan baik. Ini bisa dilihat dari Dinas Kesehatan dan Dinas Pendidikan yang konsisten menindaklanjuti kerjasama.

\section{b. Sumberdaya}

\section{Sumberdaya Manusia}

Sumberdaya manusia adalah hal yang paling dasar yang harus dimiliki organisasi. Nawawi (Ismail, 2000: 23) menjelaskan bahwa sumberdaya manusia yakni:

a) manusia yang bekerja di lingkungan suatu organisasi (sering disebut juga personil, tenaga kerja, pegawai dan karyawan)

b) potensi manusiawi sebagai penggerak organisasi dalam mewujudkan eksistensinya.

Jika melihat definisi tersebut bahwa tenaga kerja atau pegawai adalah hal terpenting dalam sebuah organisasi sebagai penggerak atau pelaksana. Akan tetapi dalam melaksanakan tugasnya jumlah pegawai juga mempengaruhi hasil yang dicapai seperti yang diuraikan oleh Edwards (Widodo, 2010: 98) bahwa no matter how clear and consistent implementation order are and no matter accurately they are transmitted, if personnel responsible for carrying out policies lack the resources to do an effective job, implementing will not effective. Ini bahwa tidak peduli bagaimana jelas, konsisten dan akurat implementasi itu diteruskan tapi jika jumlah personil yang bertanggung jawab untuk melaksanakan kebijakan kekurangan sumberdaya untuk melakukan pekerjaan yang efektif, pelaksanaan tidak akan efektif. Terkait jumlah pegawai yang ada di masingmasing dinas sebagai implementor kerjasama sister province, menurut penuturan beberapa informan sudah mencukupi, sehingga 
seharusnya melaksanakan tugas dan fungsinya untuk merealisasikan programprogram yang dikerjasamakan di dalam MoU kerjasama sister province.

\section{Sumberdaya Wewenang}

Untuk sumberdaya kewenangan yang dimaksud oleh Edwards III (Widodo, 2010:103) adalah pelaku utama kebijakan harus diberi kewenangan yang cukup untuk membuat keputusan sendiri guna melaksanakan kebijakan yang menjadi wewenangnya. Sesuai dengan penelitian sumberdaya kewenangan dari kerjasama sister province, dinas-dinas terkait memiliki wewenang yang cukup untuk mengemban tugas dan fungsi sesuai dengan fokus bidang yang dikerjasamakan. Salah satu bentuk wewenang tersebut yaitu masing-masing dinas yang dalam hal ini adalah Dinas Perindustrian dan Perindustrian (Dinperindag), BPMD, Dinas Pendidikan (Dindik), Dinas Kebudayaan dan Pariwisata (Dinbudpar) dan Dinas Kesehatan (Dinkes) berwenang menindaklanjuti kerjasama yang sudah ada dengan kerjasama teknis yang ingin dikembangkan.

Ini sekaligus menjadi nilai plus dari kerjasama sister province, di mana implementornya memiliki wewenang yang cukup besar untuk mengambil keputusan atau kebijakan yang bersangkutan langsung dengan program yang ingin dikerjakan. Contohnya adalah, Dinas Pendidikan memiliki wewenang untuk menindaklanjuti MoU sister province dengan kerjasama teknis sehingga menghasilkan sister school, meskipun dalam hal ini Dinas Pendidikan hanya sebagai fasilitator dari sekolah-sekolah yang menjalin kerjasama sister school dengan sekolah dari sister province Pemerintah Provinsi Jawa Tengah.

\section{Sumberdaya Anggaran}

Sumberdaya finansial atau anggaran sangatlah penting untuk menjalankan kebijakan. Ini sesuai dengan Edwards (Widodo, 2010:101) bahwa keterbatasan sumberdaya anggaran dapat mempengaruhi keberhasilan pelaksanaan kebijakan. menjadikan program tidak bisa dilaksanakan optimal, selain itu juga akan mempengaruhi lemahnya disposisi pelaksana. Terkait sumberdaya anggaran yang ada untuk menunjang pelaksanaan kerjasama sister province di Provinsi Jawa Tengah bahwa anggaran yang ada sudah cukup. Kalaupun ada masalah terkait anggaran, itu bisa dipastikan karena adanya anggaran-anggaran dadakan atau insidental di luar anggaran yang sudah ditetapkan.

\section{c. Struktur Birokrasi}

Implementasi kebijakan bisa jadi masih belum efektif karena struktur birokrasi yang tidak efisien, menurut Edward III. Struktur birokrasi salah satunya mencakup SOP, SOP itu meliputi pembagian tugas pokok, fungsi, tanggung jawab dan prosedur pelaksanaan. Selain itu SOP menurut Winarno (2005:150) merupakan perkembangan dari tuntutan internal akan kepastian waktu, sumber daya serta kebutuhan penyeragaman dalam organisasi kerja yang kompleks dan luas. Maka sesuai dengan hasil penelitian didapat bahwa kerjasama sister province menggunakan action plan sebagai nama lain dari SOP (standard operational procedure) untuk mengimplementasikan program dari kerjasama. Action plan yang digunakan hampir sama dengan SOP, dimana di dalamnya terdapat waktu pelaksanaan, pelaksana dan penanggungjawab. Dengan adanya action plan, pelaksanaan kerjasama sister province lebih terjadwal meskipun terkadang masih ada rencana kegiatan yang tidak bisa dilaksanakan tepat waktu.

\section{Faktor Penghambat}

\section{Disposisi}

Sebuah implementasi kebijakan akan bisa berjalan dengan baik jika pelaksana memiliki kemauan, keinginan, kecenderungan, para pelaku kebijakan untuk melaksanakan kebijakan tadi secara sungguh- 
sungguh, sehingga apa yang menjadi tujuan kebijakan dapat diwujudkan, seperti yang dituturkan Edwards III. Jika implementor memiliki disposisi yang baik, mereka bisa menjalankan atau mengimplementasikan kebijakan dengan baik sesuai dengan isi kebijakan. Sesuai hasil penelitian terkait watak pelaksana kerjasama sister province, kemauan dan keinginan dari implementor kebijakan kerjasama luar negeri sister province di Provinsi Jawa Tengah masih lemah. Hal ini bisa dilihat dari empat kerjasama sister province dengan berbagai macam bentuk kerjasama dengan melibatkan 5 (lima) dinas sebagai pelaksana kerjasama, hanya 2 (dua) yang sudah menunjukkan kemauan dan keinginananya untuk menindaklanjuti kerjasama dengan kerjasama teknis. Dinas tersebut yaitu Dinas Pendidikan (fasilitator sister school) dan Dinas Kesehatan (kerjasama dengan University of Technology, Queensland) sebagai upaya peningkatan mutu tenaga medis supaya bisa diakui internasional. Sedangkan tiga dinas lainnya, yakni BPMD, Dinas Perindustrian dan Perdagangan (Dinperindag) serta Dinas Kebudayaan dan Pariwisata (Dinbudpar) selama ini masih sebatas partisipator dalam setiap event yang dilaksanakan oleh Provinsi Jawa Tengah dalam program kerjasama sister province.

\section{Sumberdaya (kemampuan)}

Penelitian ini menemukan bahwa kemampuan bahasa asing sebagian besar pegawai di dinas-dinas pelaksana kerjasama sister province di Provinsi Jawa Tengah, masih lemah. Padahal konsekuensi dalam melakukan hubungan kerjasama luar negeri minimal menguasai bahasa Inggris. Kelemahan inilah yang menjadi kendala, sehingga komunikasi yang terjalin dari masing-masing sister province menjadi kurang komunikatif dan maksimal. Selain itu jika pegawai bisa berbahasa asing maka penggunaan guide (ketika berkunjung atau ada kunjungan) bisa dikurangi dan bisa menghemat anggaran.

\section{Struktur Birokrasi (Fragmentasi)}

Banyaknya dinas-dinas yang terlibat dalam mengimplementasikan fokus bidangbidang kerjasama dari masing-masing kerjasama sister province di Provinsi Jawa Tengah mempengaruhi penyebaran tanggungjawab kepada dinas-dinas yang berbeda. Ini menyulitkan koordinasi ataupun komunikasi antara dinas satu dengan lainnya. Seperti yang diutarakan oleh Edwards III tentang fragmentasi. Fragmentasi merupakan penyebaran tanggung jawab suatu kebijakan kepada beberapa badan yang berbeda sehingga memerlukan koordinasi.

Jika disesuaikan dengan pendapat di atas dengan hasil penelitian maka kerjasama sister province dilaksanakan oleh 5 (lima) yang berbeda sudah memperlihatkan adanya fragmentasi. Koordinasi hanya secara vertikal Biro Otda dengan Dinas-dinas terkait sedangkan secara horisontal belum ada.

\section{PENUTUP Kesimpulan}

Pelaksanaan kerjasama sister province di Provinsi Jateng kurang maksimal dikarenakan masih minimnya program kerjasama yang belum terealisasi. Beberapa sister kurang disiplin dalam mentaati MoU yang disepakati. Beberapa dinas belum menindaklanjuti program kerjasama dengan program yang lebih teknis. Selain itu sebagian besar para implementor masih lemah dalam penguasaan bahasa asing. Banyaknya dinas yang terlibat menyulitkan para implementor dalam koordinasi.

\section{DAFTAR PUSTAKA}

Kusumanegara, Solahuddin, 2010, Model dan Aktor dalam Kebijakan Publik, Gava Media, Yogyakarta

Peraturan Gubernur Jawa Tengah No. 4 Tahun 2010 tentang Pedoman Pelaksanaan Kerjasama Provinsi Jawa Tengah Dengan Pihak Luar Negeri. 
Peraturan Menteri Dalam Negeri No.3 Tahun 2008 tantang Pedoman Pelaksanaan Kerjasama Daerah Dengan Pihak Luar Negeri

Peraturan Menteri Dalam Negeri (Permendagri) No. 1 Tahun 1992 tentang Penyelenggaraan Hubungan dan Kerjasama Luar Negeri

Subarsono, 2005, Analisa Kebijakan Publik Konsep, Teori dan Aplikasi, Pustaka Pelajar, Yogyakarta
Sururi, Ahmad. 2009. Perjanjian Kerjasama Sister Province Jawa Tengah Queensland (Studi Evaluatif tentang Efektifitas dan Kepentingan Aktor di Jawa Tengah) (Tesis).Yogyakarta: UGM

Undang-Undang No 32 Tahun 2004, Tentang Pemerintahan Daerah

Widodo, Joko, 2010, Analisis Kebijakan Publik: Konsep dan Aplikasi Analisis Proses Kebijakan Publik, Bayu Media, Malang 